\title{
The Effect of National Culture on Debt Risk: An Empirical Analysis of "Belt and Road" Countries
}

\author{
Wang Lu, Li Yanxi, Ouyang Shanshan
}

Faculty of Management and Economics, Dalian University of Technology, Dalian, Liaoning Province, China

Keywords: National culture; debt risk; "Belt and Road” Initiative

\begin{abstract}
This paper examines the relation between three dimensions of national culture (individualism, short-term orientation and uncertainty avoidance) and debt risk using a sample of 65 BRI countries during the period from 2008 to 2017. The empirical results showthat strong individualism and short-term orientation leads to higher national debt risk, while strong uncertainty avoidance leads to lower national debt risk. Further research indicates that international cooperation plays a moderating role in the relationship between national culture and debt risk. It alleviates the negative effect of individualism and short-term orientation on national debt risk. The study proposes to consider national culture in the assessment of the debt risk of BRI countries and it provides empirical evidence and supplementationto the existing literatures from informal institutional perspective.
\end{abstract}

\section{Introduction}

The "Belt and Road" Initiative (BRI) aims at win-win cooperation to promote common development and achieve common prosperity. It fully relies on bilateral and multilateral cooperation mechanisms of BRI countries to build a broader, higher-level and deeper regional cooperation platform. For example, more sufficient infrastructure financing has been provided to BRI participants.However, as the world's debt risk is piling up since the 2008 financial crisis, some BRI countries have heavy debt burden and high debt risk. For example, Mongolia, Pakistan, Sri Lanka and Lebanon have defaulted on their debts in recent years, which attracted internationalattention. National debt risk has become one of the important challenges in the construction of BRI. Inthe second Belt and RoadSummit, the Ministry of Finance of China has released the BRI debt sustainability analysis framework, which shows that the Chinese government has realized the potential debt risks of BRI countries. It needs to beemphasized in the next step to promote the high-quality development of BRI.

The existing literatures on national debt risk are mainly based on the standard model of national debt, which measures the level of national income and expenditure, and analyzes the underlying factors including single industrial structure and revenue channel, imperfect tax system, rigid fiscal expenditure, and irrational fiscal arrangement[1-4].Admittedly, for developing countries, one of the most obvious reasons of debt risk is capital shortage and inefficient capital management. However, debt risk is not unique to the developing countries, developed countries have encountered national debt crisis. Therefore, morepossible reasons should be further investigated. In a global survey on the factors that provide the conditions for the credit crunch by PricewaterhouseCoopers and the Economist, the results show that 31\% of survey participants put the blame on "monetary policy", $58 \%$ on "ineffectiveregulatory oversight", and 73\% on "culture and excessive risk-taking”[5]. Therefore, cultural characteristics could be one reason whichshould be further analyzed.

There are widespread supporting literatures for the importance of culture in the economy [6-8]. In the mainstream economic and financial theory, itis assumed that agents are fully informed and rational, with identical beliefs and preferences, seeking contracts that align the interests of all parties and best respond to information asymmetry, agency costs, and moral hazard. However, in practice, agents are bounded rational and contracts are incomplete due to the impossibility of specifying all contingencies. Therefore, values, customary practices, preferences and ethics, which collectively form part of national culture,have been used as the basis for decision-making.A 
growing number of financial researches indicate that culture has a significant impact on capital structure and cost of debt[9]. For example, Sekely\& Collins [10] is one of the earliest to point out that cultural differences play an important role in explaining differences in corporate capital structures in 23 countries.Chui et al. [11] pointout that cultural differences affect the cost of corporate debt based on a dataset of 33 countries.Wang \&Esqueda [12] find that national culture influences the leverage ratio of domestic enterprises, among which the leverage ratio is higher in the enterprises with individualistic and short-term orientated culture.

Most studies on the economic impact of culture are based on traditional economic lines, which explain from increasing the costs of doing business by raising informational asymmetries and transaction costs, rather than a separate influence that stems from societal differences in people's values, preferences, and risk perception, that is, how people view the world, how they interact with others, and how they pursue the goals they consider to be appropriate.For example, people pursue self-satisfaction or the interests of thegroup. People prefer credit consumptionor bank saving due to difference time orientation culture. People tend to be more risk-taking or risk adverse.

Because of cultural differences of BRI countries, this paper identifies three dimensions of national culture, pioneered by Hofstede et al. [13], which are related to debt risk.It analyzes the impact of national culture, including individualism/collectivism, long-term/short-term orientation, and uncertainty avoidance, on national debt risk from the perspective of social differences under different cultural backgrounds. Our research provides empirical evidence for identifying and assessing risk in international debt investment and complements the existing literatures from the informal institutional perspective.

The rest of this article is organized as follows. In the next section, we review the literature and provide the theoretical background to clarify the relationship between religious heterogeneity and sovereign debt risk. The third section presents the research design, where data, variables and model specification are illustrated. The fourth section provides the empirical analysis. The last section concludes the paper

\section{Literature Review}

Hofstede and Bond [14] defined culture as "the collective programming of the mind that distinguishes the members of one category of people from those of another.Culture is composed of certain values, which shape behavior as well as one's perception of the world." Individualism/collectivism, masculinity/femininity, power distance, uncertainty avoidance, long-term/short-term orientation, and indulgence/restraint constitute Hofstede's six cultural dimensions [13]. Existing research on culture and economy is largely based on these six aspects[15-20].

Individualism refers to the loose relationship between people in the society. Individuals mainly care about themselves and their family members. The opposite is collectivism when people are strongly integrated and loyal to a cohesive group [21]. Individualism and collectivism are regarded as two most important groups in world culture, which have constantly attracted the attention from the academics. Gorodnichenko\& Roland [17] explore which dimensions of national culture have an impact on the country's long-term economic growth. The empirical results show that individualism and uncertainty avoidance have significant positive effects on the long run growth. Individualistic cultureemphasizes more on individuals' interests and achievementsbut less on group goals.Mourouzidou-Damtsa et al. [20] point out that cultural values are deeply rooted in society and influence financial decision-making. The study investigates bank risk from a cultural perspective and finds that although banks are rigidly regulatedfor affecting the stability of the national financial system, culture still has a significant impact on domestic bank risk. Specifically, it reports a positive relation between the cultural values of individualism and bank risk-taking.The reason is that banks operating in individualistic societies would increase risk to meet the demand of customers and shareholders for high returns and profit maximization, while less consideration is given to the negative impact of bank risks on the country as a whole. Lim et al. [19]illustrate cross-country disparities in earnings management could be influenced by disparities in bank oversight and 
regulation across countries, as well by softer dimensions such as national culture which could affect excessive risk-taking. The empirical study explore the relationship between national culture and bank managementbased on a sample of banks in 39 countriesfrom 1993 to 2006.It finds that the degree of earnings management is higher in a society with high individualism and low uncertainty avoidance. A further analysis of bank performance during the financial crisis period shows that banks in culture that encourages higher risk-taking behaviorexperienced larger losses.Generally, the individualistic culture promotes national economic development, but also increases economic risks.

Existing research has also focused on other cultural dimensions. Kristjansdottir et al. [18]analyze the influence of national culture on international trade based on the data of 21 countries. Theyfind that, of the five Hofstede dimensions, only the masculinitypositivelyinfluence the international trade. Masculinitydominated countries tend to be competitive, confident, and ambitious, and prefer accumulation of wealth. Chui et al. [ $\left[11^{]}\right.$found that the cultural dimension of mastery, whichcould be interpreted as the dimension of power distance close to Hofstede,has a negative impact on debt ratio. Fidrmuc\& Jacob [16]pointed out that agency conflict is more seriousin highly individualistic society because peopleinclineto pursue personal interestsrather than profit maximization of shareholders or enterprises. Therefore, companies in highindividualistic countries tend to increase debts to reduce agency costs. Wang \&Esqueda [12]analyze leverage ratios in different culture from 1996 to 2010.The study points out cultural characteristics can explain the capital structure of cross-listing in emerging markets. Corporate debt leverage is higher in countries with high individualism and indulgence, but lower in countries with masculinity, high power distance, and high uncertainty avoidance.Based on a sample of 3438 Banks in 48 countries, Boubakri et al. [15] examine whether national culture play an important role in determining bank performance during the financial crisis. The empirical results show that banks in a society with high individualism perform worse, while those in a society with high uncertainty avoidance and high power distance culture perform better.

\section{Theory and Hypothesis}

Lichte et al. [22]indicate that values are the essence of culture when seen as meanings, symbols, and assumptions about what is right or wrong, legitimate or illegitimate, that underlie the prevailingnorms and practices in society. All societies confront similarfundamental problems or issues in regulating human activity. The main dimensions of culture are derived from these issues, because the preferred methods of dealing with them are conveyed in different social values.This paper selects three cultural dimensions, includingindividualism/collectivism, long-term/short-term orientation, and uncertainty avoidance, to discuss the impact of national culture on debt risk and corresponding influencing mechanisms from the perspective of social differences under different cultural backgrounds.

Individualism/collectivism is a measure of whether a society is more concerned with the interests of the individual or those of the collective. Individualismemphasizes more on personal interests, achievement, self-orientation and autonomy[21]. Individualism and collectivism reflect the social tendency and preference between self-actualization and compliance with social responsibility and moral behaviour [23]. Individualism emphasizes more on the maximization of personal interests and less on the interests of others and the society as a whole. Therefore, financial institutions in the individualistic culture increase potential risks in order to cater to the demand of customers and shareholders for high returns and profit maximization. They consider less about the negative impact on the national economy [20]. One of the direct causes of the subprime crisis is that financial institutions abandonthe basic principles of the financial market to pursue their own interests. On the contrary, financial institutions in collectivist culturepay more attention to the consistency and the observance of social rules. The micro-level debt risk of financial institutions will spread to the macro-level. Therefore, when the marketconfronts illiquidity, the government has to step in and expanded expenditure to make up for market credit with sovereign credit. National finance is used to guarantee the microdefault risk of financial institutions and enterprises. As a result, the debt risk of the market has been eased, but the government's fiscal deficit has increased, resulting in a 
highernational debt burden and higher national debt risk.Based on these statements, this paper proposes the following hypothesis:

H1a: Individualism has a positive effect on national debt risk.

Long-term/short-term orientation measures the extent to which people can accept the delay of the fulfillment of their material, emotional, and social needs. In a long-term oriented society, the world is constantly changing. People alwaysshave greater concerns with the future and value persistenceand thriftiness. They do not expect their needs and desires to be met immediately. Contrarily, the world is unchanged in short-termoriented society, thus past behavior provides society with a moral compass to fall back on. People focus on traditions and social obligations, payless attention on thrift and tenacity, and expect needs and desires to be met as quickly as possible[24].

National debt risk could be affected by short-term orientation due to the following reasons. First, peopleof short-termorientation cultures are lessreceptive to delaying the satisfaction of their material and social needs. From the individual level, people tend tooverspend in order to achieve personal satisfaction. It could be implied that short-term oriented culture promotes more debts and less savings. From the national level, the government promotes consumptive fiscal expenditure and restrains accumulative expenditure in order to meet the demand of people, which would be harmful to the national economic development in the long run.Second, people prefer living in the moment and enjoying their life rather than saving or preparing for the futurein the short-term oriented culture. People consider debt to bedistant from present, thus they borrow more and save less, and correspondinglyless corporatecash holdings. However, in a long-termoriented culture, people consider adverse credit events as being more imminent. Therefore, there will be more precautionary savings, and correspondingly higher corporate cash holdings [25-26]. Third, the governmenttends to borrow more to finance inflowsduring its tenure in short-termoriented culture. To increase current lending capacity, short-termoriented governmentestablishes links between sovereign debt and the domestic financial sector, making foreign debtor more willing to lend in anticipation of higher domestic default costs. Short-termoriented governmentis more concerned about current cash flows rather than the accumulation of debt to be repaid in the future. They hand over their future debts to the next government [27]. Based on these statements, this paper proposes the following hypothesis:

H1b: Short-term orientation has a positive effect on national debt risk.

Uncertainty avoidance measures the extent of tolerance for ambiguity and uncertainty in a society.Societies with high uncertainty avoidance tend to avoid and control uncertainty through formal channels when uncertain events or unconventional situations occur. Uncertainty can be coped with three mechanisms including technology,law, andreligion.Contrarily, cultures with lowerlevel of uncertainty avoidance are more tolerant of different opinions and philosophical and religious viewswith fewer rules and regulations[13].

National debt risk could be affected byuncertainty avoidance due to the following reasons.First, different cultures have different perceptions of risk. Frijns et al. [28]point out that the national culture influences the risk perception of the CEO. It is found that the uncertainty avoidance leads to higher risk perception resulting in fewer cross-border acquisition behaviors. In societies with high uncertainty avoidance, people have a stronger perception of the cost of risk and try to minimize uncertainty and avoid risky behaviors. On the contrary, in the societies with low uncertainty avoidance, people's perception of thecost of risk is weaker [29]. Second, uncertainty avoidance affects people's risk tolerance.Higher uncertainty avoidance could lead to lower risk-taking, as people in such cultures have a higher level of anxiety, and thus prefer a more predictable situation. People inlower uncertainty avoidance canenjoy their lives withuncertainty and risk, which makes them relatively less risk-averse [30]. Third, uncertainty avoidance affects people's sensitivity to stress. A debt scenario that causes stress in a culture of high uncertainty avoidance might not be enough to cause stress in a culture of low uncertainty avoidance.It could be implied that high uncertainty avoidance reduces debt.One of the characteristics of modern risk society is that personal risk has been largely transformed into national risk. When the majority of the public believes that the state shouldbail out individuals, personal risk could be transformed into national risk. 
Based on these statements, this paper proposes the following hypothesis:

H1c: Higher uncertainty avoidance has a negative effect on national debt risk.

International cooperation may affect the debt risk of a country in terms of its solvency and willingness to pay. From the perspective of solvency, one of the important reasons for the debt overburden of some countries is its imperfect industrial structure. International cooperation, especially industrial cooperation among countries with strong complementarities, is conducive to the economic development of countries and thus to the alleviation of their debt risks. From the perspective of debt repayment, debt default may negatively affect international trade and financing [31].Countries with a high degree of international cooperation shows the willingness to engage in transnational exchanges and cooperation for mutual benefit and pay more attention to maintaining their international reputation to avoid losses in international trade and financing, thus they have a strong willingness to pay. From the perspective of culture, international cooperation plays a certain role in adjusting and correcting the risk taking and short-sighted behavior caused by culture, so as to alleviate the negative impact of some cultural dimensions on debt risk. Based on these statements, this paper proposes hypothesis 2:

H2: When international cooperation is high, the negative impact of culture on national debt risk is weakened.

H2a: When international cooperation is high, the negative impact of individualismon national debt risk is weakened.

H2a: When international cooperation is high, the negative impact of short-term orientationon national debt risk is weakened.

\section{Research Design}

\subsection{Data and variable}

The total number of BRI countries varies according to different information sources. It has also been increasing during the past years. Therefore, we choose a conservative definition of 65 countries with reference to the Industrialization of the Belt and Road Countries Report published by the China Academy of Social Science. Therefore, our initial sample consists of data of 65 BRI countries from 2008 to 2017. Country-year observations with incomplete information are excluded to obtain a total of 500 country-year observations.

National debt risk will be regarded high if the government has a high propensity of failing to service its debt in the absence of adjustment[32]. Two aspects are encompassed here: solvency and liquidity. Debt solvency refers to the account surplus that can repay the debt of the principal and interest. From the sustainable point of view, it means that the discounted value of current and future expenditures shall not be greater than the discounted value of current and future incomes minus earlier liabilities. In terms of liquidity, there will be a lack of liquidity if a country's liquid assets and available financing are insufficient to roll over maturing debt. In the case of illiquidity, the interest rate of debt will rise, which may lead to the difficulty of refinancing the country, and the marginal interest rate can be infinite, ultimately affecting the solvency of the country. In fact, solvency and liquidity cannot be clearly distinguished. Debt sustainability requires both solvency and liquidity. Therefore, this paper selects three indicators (fordebt, debtserv, Intliq) to measure national debt risk from both solvency and liquidity perspectives, in consistent with Kraay [33].

The data measuring different culture dimensionsare draw from Hofstede's survey of cultural values (Value Survey Module, VSM), which coversdifferent cultural dimensions in 112 countries around the world. This paper employs data on three cultural dimensions: individualism/collectivism, long-term/short-term orientation and uncertainty avoidance. The missing values are filled in with the average of neighbor country data. National culture values are extremely stable over time since a country's scoreon each dimensiondoes not provide an absolute value but rather its position relative to other countries[13].

This paper also adopts the number of Bilateral Investment Treaties (BIT) signed by a country as an indicator of international cooperation. BIT is signed between two governments to promote 
bilateral investment between signatories. The existing literatures show that BIT significantly facilitates foreign capital inflow[34-36]. This indicator reflects the level of openness and cooperation at the national level.

In order to explore the relationship between culture and national debt risk, this paper controls the factors of economy, formal institution and informal institution consistent with Elgin \&Uras. All variables are specified in Table 1.

\section{Table 1 Definition and calculation of variables}

\begin{tabular}{|c|c|c|c|}
\hline \multirow{3}{*}{$\begin{array}{l}\text { National } \\
\text { debt risk } \\
\text { (Derisk) }\end{array}$} & Fordebt & $\begin{array}{l}\text { Gross foreign debt in a given year is divided by the Gross Domestic Product. It is } \\
\text { rescaled and converted to a risk point with the highest risk of } 50 \text { and lowest risk of } \\
0 .\end{array}$ & \multirow{3}{*}{ World Bank } \\
\hline & Debtserv & $\begin{array}{l}\text { The foreign debt service, for a given year, is divided by the sum of the total } \\
\text { exportsof goods and services for that year. It is rescaled and converted to a risk } \\
\text { point with the highest risk of } 50 \text { and lowest risk of } 0 \text {. }\end{array}$ & \\
\hline & Intliq & $\begin{array}{l}\text { The total official reserves for a given year, including official holdings of gold, but } \\
\text { excluding the use of IMF credits and the foreign liabilities ofthe monetary } \\
\text { authorities, is divided by the average monthly merchandise import cost. It is } \\
\text { rescaled and converted to a risk point with the highest risk of } 50 \text { and lowest risk of } \\
0 .\end{array}$ & \\
\hline \multirow{3}{*}{$\begin{array}{l}\text { Culture } \\
\text { (Cul) }\end{array}$} & IDV & $\begin{array}{l}\text { IDV measures the level of individualism, which is expressed on a scale that runs } \\
\text { roughly from } 0 \text { to 100. A larger value of IDV indicates stronger individualistic } \\
\text { culture. }\end{array}$ & \multirow{3}{*}{$\begin{array}{l}\text { Hofstede } \\
\text { Culture } \\
\text { Hofstede et } \\
\text { al. (2010) }\end{array}$} \\
\hline & STO & $\begin{array}{l}\text { STO measures the level of short-term orientation, which is expressed on a scale } \\
\text { that runs roughly from } 0 \text { to } 100 \text {. A larger value of STO indicates } \\
\text { strongershort-term oriented culture. }\end{array}$ & \\
\hline & UAI & $\begin{array}{l}\text { UAI measures the level of uncertainty avoidance, which is expressed on a scale } \\
\text { that runs roughly from } 0 \text { to } 100 \text {. A larger value of UAI indicates } \\
\text { strongeruncertainty avoidance culture. }\end{array}$ & \\
\hline $\begin{array}{l}\text { Internation } \\
\quad \text { al } \\
\text { cooperatio } \\
\text { n (Intcop) }\end{array}$ & BIT & The total number of Bilateral Investment Treaties (BIT) signed by a country. & UNCTAD \\
\hline \multirow{4}{*}{$\begin{array}{l}\text { Economic } \\
\text { factors }\end{array}$} & GDPp & $\begin{array}{c}\text { Economic development: the natural logarithm of Gross Domestic Product per } \\
\text { capita }\end{array}$ & \multirow{4}{*}{$\begin{array}{l}\text { World Bank } \\
\text { and IMF }\end{array}$} \\
\hline & Growth & Economic growth: the growth rate of Gross Domestic Product & \\
\hline & Infl & $\begin{array}{l}\text { Inflation rate: inflation as measured by the consumer price index reflects the } \\
\text { annual percentage change in the cost to the average consumer of acquiring a } \\
\text { basket of goods and services. }\end{array}$ & \\
\hline & Unem & Long-term unemployment rate & \\
\hline \multirow{2}{*}{$\begin{array}{l}\text { Formal } \\
\text { institution }\end{array}$} & Law & $\begin{array}{l}\text { Law refers to the strengthand impartiality of the legal system is considered, while } \\
\text { Order is an assessment ofpopular observance of the law. A high value refers to } \\
\text { aneffective judicial system and sanction. }\end{array}$ & \multirow{4}{*}{ ICRG } \\
\hline & Stab & $\begin{array}{l}\text { Government stability:the government's ability to carry out its declared } \\
\text { program(s), and itsability to stay in office. }\end{array}$ & \\
\hline \multirow{2}{*}{$\begin{array}{l}\text { Informal } \\
\text { institution }\end{array}$} & Bureau & $\begin{array}{l}\text { Bureaucracy quality: the institutional strength and quality of the bureaucracy. } \\
\text { High valuerefers to countries where the bureaucracy has the strength and expertise } \\
\text { to govern without drastic changesin policy or interruptions in government } \\
\text { services. }\end{array}$ & \\
\hline & Democ & $\begin{array}{c}\text { Democratic accountability: a measure of how responsive government is to its } \\
\text { people. }\end{array}$ & \\
\hline
\end{tabular}




\subsection{Model specification}

To test the hypothesis, this paper includes all available control variables to be consistent with the above literature and constructs a multilinear regression model by applying the ordinary least square method. The regression equationsare constructed as follows:

$$
\begin{array}{r}
\text { Derisk }=\beta_{0}+\beta_{1} \text { Cul }+\beta_{2} \text { GDPp }+\beta_{3} \text { Growth }+\beta_{4} \text { Inf }+\beta_{5} \text { Unem }+\beta_{6} \text { Law }+\beta_{7} \text { Stab }+\beta_{8} \text { Bureau }+\beta_{9} \text { Democ }+\varepsilon(1) \\
\text { Derisk }=\beta_{0}+\beta_{1} \text { Cul }+\beta_{2} \text { Intcop }+\beta_{3} \text { Cul } \times \text { Intcop }+\beta_{4} \text { GDPp } \\
+\beta_{5} \text { Growth }+\beta_{6} \text { Inf }+\beta_{7} \text { Unem }+\beta_{8} \text { Law } \\
+\beta_{9} \text { Stab }+\beta_{10} \text { Bureau }+\beta_{11} \text { Democ }+\varepsilon(2)
\end{array}
$$

The relation between culture and national debt risk is explored by controlling other economic and institutional factors in model 1. In order to explore the moderating effect of international cooperation, an interaction term of culture and international cooperation is added to the regression in model 2.

Although the emphasis of each indicator in Hofstede's cultural dimension is different, the information carried by indicators overlaps with each other, which will restrict the interpretation of multiple relationships [38].Gorodnichenko\& Roland [17] pointed out that there is a significant negative correlation between individualism and uncertainty avoidance.Lim et al. [19]pointed out that individualism was significantly correlated with uncertainty avoidance and power distance. They state that even if multicollinearity was tested, regression results should be interpreted with cautionwhen different cultural dimensions are included in a regression. Therefore, each cultural dimension has been put into the regression separately to avoidmulticollinearity in our study by referring to Gorodnichenko\& Roland [17].

\section{Empirical Results}

Table 2 presents the summary statistics. The mean values of the variables are close to the median, indicating that the sample tends to be normally distributed. It shows the lowest scores of individualism, short-term orientation and uncertainty avoidance are 14.000, 12.594 and 8.000, respectively. The highest scores are $80.000,93.199$ and 100.000 , respectively. The average values are 39.673, 43.097 and 67.042, respectively. The results of Pearson's correlation coefficient matrix between variables show no multicollinearity problem existing. The statistics are omitted due to

\begin{tabular}{|c|c|c|c|c|c|}
\hline & Min & Max & Mean & Median & Stdev \\
\hline Fordebt & 0.833 & 50.000 & 26.269 & 28.125 & 6.437 \\
\hline Debtserv & 5.000 & 50.000 & 43.416 & 47.500 & 3.618 \\
\hline Intliq & 0.833 & 50.000 & 27.279 & 30.000 & 8.274 \\
\hline IDV & 14.000 & 80.000 & 39.673 & 38.000 & 15.309 \\
\hline STO & 12.594 & 93.199 & 43.097 & 40.169 & 20.570 \\
\hline UAI & 8.000 & 100.000 & 67.042 & 69.167 & 19.846 \\
\hline BIT & 1.000 & 119.000 & 52.456 & 49.000 & 23.101 \\
\hline GDPp & -37.147 & 19.592 & 3.009 & 3.393 & 3.262 \\
\hline Growth & 2.258 & 7.949 & 4.734 & 4.761 & 0.599 \\
\hline Infl & -26.866 & 75.201 & 5.420 & 3.539 & 5.577 \\
\hline Unem & 0.136 & 24.000 & 6.996 & 4.949 & 3.274 \\
\hline Law & 1.500 & 5.000 & 3.661 & 4.000 & 0.652 \\
\hline Stab & 4.042 & 11.500 & 7.328 & 7.500 & 1.277 \\
\hline Bureau & 0.167 & 6.000 & 3.629 & 4.000 & 0.915 \\
\hline Democ & 1.000 & 4.000 & 2.026 & 2.000 & 0.475 \\
\hline
\end{tabular}
word limit.

Table 2 Summary statistics

Table 3 reports the main regression results of model 1. When Fordebt is used as the dependent 
variable, the adjusted R-square is 0.321 for IDV, 0.329 for STO and 0.324 for UAI, indicating all regressions have good explanatory power and the F-statistics in all cases reject the null hypothesis of joint insignificance. The coefficient of IDV is 0.167 and is positively significant at $1 \%$ level, showing that national debt risk increases as the individualism becomes stronger in a country. The coefficient of STO is 0.184 and positively significant at $1 \%$ level as well. The coefficients of IDV and STO are positively significant in panel B and panel C. The empirical results indicate that both stronger individualism and short-term orientation lead to higher national debt risk.The coefficients of UAI are $0.189,-0.004$ and -0.120 in panel A, B and C, respectively. The negative coefficients are significant at $10 \%$ and $5 \%$ level, correspondingly, but the positive coefficient is insignificant.The results show that high uncertainty avoidance leads to low national debt risk. Additionally, the findings illustrate that IDV and STO have a greater impact on solvency, while UAI has a greater impact on liquidity.

Table 4 reports the regression results of model 2. In the first regression, the coefficient of IDV is 0.160 , and the coefficient of interaction between IDV and BIT is -0.005 , which is significant at the $10 \%$ level. In the second regression, the coefficient of interaction between IDV and BIT is significantly negative as well, revealing the moderating effect of BIT in the relationship between IDV and national debt risk. In terms of STO, the coefficients of interaction are $-0.020,-0.134$, and -0.377 , respectively, which are all significant. Our findings show that the negative impact of short-term orientation on national debt risk is weakenedwhen the international cooperation is high.

Table 4Culture, international cooperation and national debt risk

\begin{tabular}{|c|c|c|c|c|c|c|}
\hline \multirow[b]{2}{*}{ IDV } & \multicolumn{2}{|c|}{ (1) Fordebt } & \multicolumn{2}{|c|}{ (2) Debtserv } & \multicolumn{2}{|c|}{ (3) Intliq } \\
\hline & $0.160 * * *$ & & $0.075 *$ & & 0.015 & \\
\hline & $(3.606)$ & & $(1.742)$ & & $(0.296)$ & \\
\hline \multirow[t]{2}{*}{ IDV $\times$ BIT } & $-0.005^{*}$ & & $-0.114^{* *}$ & & 0.130 & \\
\hline & $(-1.688)$ & & $(-2.299)$ & & $(1.443)$ & \\
\hline \multirow[t]{2}{*}{ STO } & & $0.202^{* * *}$ & & $0.158 * * *$ & & $0.201^{* * *}$ \\
\hline & & $(4.911)$ & & (3.504) & & $(4.340)$ \\
\hline \multirow[t]{2}{*}{ STO $\times$ BIT } & & $-0.020^{*}$ & & $-0.134 * * *$ & & $-0.377 * * *$ \\
\hline & & $(-0.444)$ & & $(-2.707)$ & & $(-7.390)$ \\
\hline \multirow[t]{2}{*}{ BIT } & $-0.113^{* *}$ & $-0.154 * * *$ & $-0.106 * *$ & $-0.128 * *$ & -0.025 & $-0.293 * * *$ \\
\hline & $(-2.413)$ & $(-3.349)$ & $(-2.063)$ & $(-2.540)$ & $(-0.452)$ & $(-5.682)$ \\
\hline \multirow[t]{2}{*}{ GDPp } & 0.022 & 0.007 & $-0.085 * *$ & $-0.086 * *$ & $-0.167 * * *$ & $-0.151^{* * *}$ \\
\hline & $(0.559)$ & $(0.175)$ & $(-1.972)$ & $(-2.036)$ & $(-3.603)$ & $(-3.467)$ \\
\hline \multirow[t]{2}{*}{ Growth } & 0.009 & 0.026 & 0.063 & $0.086^{*}$ & -0.039 & -0.007 \\
\hline & $(0.222)$ & $(0.622)$ & $(1.391)$ & $(1.916)$ & $(-0.801)$ & $(-0.155)$ \\
\hline \multirow[t]{2}{*}{ Infl } & 0.000 & -0.006 & 0.069 & 0.053 & $0.202 * * *$ & $0.173 * * *$ \\
\hline & $(0.001)$ & $(-0.164)$ & $(1.594)$ & $(1.243)$ & $(4.342)$ & (3.921) \\
\hline \multirow[t]{2}{*}{ Unem } & $0.109 * *$ & $0.147 * * *$ & $0.275^{* * *}$ & $0.284 * * *$ & -0.017 & $-0.085 *$ \\
\hline & $(2.486)$ & $(3.384)$ & $(5.760)$ & (5.989) & $(-0.322)$ & $(-1.745)$ \\
\hline \multirow[t]{2}{*}{ Law } & $0.221 * * *$ & $0.238 * * *$ & $0.147^{* * *}$ & 0.119 ** & 0.038 & -0.004 \\
\hline & $(4.495)$ & $(5.094)$ & $(2.739)$ & $(2.329)$ & $(0.657)$ & $(-0.007)$ \\
\hline \multirow[t]{2}{*}{ Stab } & -0.035 & -0.072 & 0.025 & -0.003 & 0.046 & -0.020 \\
\hline & $(-0.721)$ & $(-1.494)$ & $(0.477)$ & $(-0.066)$ & $(0.816)$ & $(-0.373)$ \\
\hline \multirow[t]{2}{*}{ Bureau } & $-0.233 * * *$ & $-0.179 * * *$ & -0.048 & -0.030 & -0.067 & -0.077 \\
\hline & $(-4.905)$ & $(-3.608)$ & $(-0.929)$ & $(-0.548)$ & $(-1.197)$ & $(-1.394)$ \\
\hline \multirow[t]{2}{*}{ Democ } & $0.495 * * *$ & $0.498 * * *$ & $0.272 * * *$ & $0.292 * * *$ & $0.159 * * *$ & $0.218 * * *$ \\
\hline & $(9.394)$ & $(9.473)$ & $(4.724)$ & $(5.083)$ & $(2.567)$ & $(3.700)$ \\
\hline $\mathrm{R}^{2}$ & 0.345 & 0.359 & 0.218 & 0.234 & 0.098 & 0.194 \\
\hline Adj-R ${ }^{2}$ & 0.330 & 0.344 & 0.199 & 0.216 & 0.077 & 0.175 \\
\hline $\mathrm{F}$ & $22.417 * * *$ & $23.838 * * *$ & $11.835^{* * *}$ & $12.984 * * *$ & $4.625 * * *$ & $10.215^{* * *}$ \\
\hline
\end{tabular}

*** significant at the $1 \%$ level, ** significant at the $5 \%$, significant at the $10 \%$.

Robustness tests have also been conducted. Firstly, financial risk rating provided by ICRG, which gives a comprehensive assessment of a country's financial risk, is employed as an explanatory variable. The empirical results show that culture has a positive impact on financial risk and the moderating effect of international cooperation is significant as well. Besides, considering the heteroscedasticity issue, the model is regressed to obtain the standard error of heteroscedasticity robustness. 
Table 3 Culture and national debt risk

\begin{tabular}{|c|c|c|c|}
\hline \multicolumn{4}{|c|}{ Panel A:Fordebt } \\
\hline & $(1)$ & (2) & (3) \\
\hline \multirow[t]{2}{*}{ IDV } & $0.167 * * *$ & & \\
\hline & $(3.844)$ & & \\
\hline \multirow[t]{2}{*}{ STO } & & $0.184 * * *$ & \\
\hline & & $(4.526)$ & \\
\hline \multirow[t]{2}{*}{ UAI } & & & 0.189 \\
\hline & & & $(1.141)$ \\
\hline \multirow[t]{2}{*}{ GDPp } & 0.035 & 0.021 & 0.036 \\
\hline & $(0.891)$ & $(0.535)$ & $(0.922)$ \\
\hline \multirow[t]{2}{*}{ Growth } & 0.005 & 0.017 & -0.011 \\
\hline & $(0.129)$ & $(0.415)$ & $(-0.272)$ \\
\hline \multirow[t]{2}{*}{ Infl } & -0.008 & -0.014 & 0.002 \\
\hline & $(-0.201)$ & $(-0.362)$ & $(0.053)$ \\
\hline Unem & $0.103^{* * *}$ & $0.144 * * *$ & $0.079 *$ \\
\hline & $(2.365)$ & $(3.355)$ & $(1.777)$ \\
\hline Law & $0.186^{* * *}$ & $0.202^{* * *}$ & $0.220^{* * *}$ \\
\hline & $(3.886)$ & $(4.415)$ & $(4.852)$ \\
\hline Stab & -0.016 & -0.044 & -0.010 \\
\hline & $(-0.336)$ & $(-0.909)$ & $(-0.202)$ \\
\hline Bureau & $-0.218^{* * *}$ & $-0.164 * * *$ & $-0.149 * * *$ \\
\hline & $(-4.600)$ & $(-3.322)$ & $(-2.909)$ \\
\hline Democ & $0.471^{* * *}$ & $0.469 * * *$ & $0.449 * * *$ \\
\hline & $(9.002)$ & $(9.077)$ & $(8.416)$ \\
\hline $\mathrm{R}^{2}$ & 0.334 & 0.341 & 0.337 \\
\hline Adj-R $^{2}$ & 0.321 & 0.329 & 0.324 \\
\hline $\mathrm{F}$ & $26.133^{* * *}$ & $27.057 * * *$ & $26.517 * * *$ \\
\hline & & & \\
\hline & (1) & (2) & (3) \\
\hline IDV & $0.052 *$ & & \\
\hline & $(1.691)$ & & \\
\hline STO & & $0.127 * * *$ & \\
\hline & & $(2.863)$ & \\
\hline UAI & & & $-0.004^{*}$ \\
\hline & & & $(-1.882)$ \\
\hline GDPp & $-0.083^{*}$ & $-0.086 * *$ & $-0.089 * *$ \\
\hline & $(-1.922)$ & $(-2.024)$ & $(-2.059)$ \\
\hline Growth & 0.063 & $0.076^{*}$ & 0.059 \\
\hline & $(1.392)$ & (1.693) & $(1.300)$ \\
\hline Infl & 0.064 & 0.059 & 0.064 \\
\hline & $(1.474)$ & $(1.371)$ & $(1.475)$ \\
\hline Unem & $0.288^{* * *}$ & $0.307 * * *$ & $0.296^{* * *}$ \\
\hline & $(6.051)$ & $(6.550)$ & $(6.073)$ \\
\hline Law & $0.128 * *$ & $0.114^{* *}$ & $0.149 * * *$ \\
\hline & $(2.440)$ & $(2.286)$ & $(2.994)$ \\
\hline Stab & 0.041 & 0.019 & 0.044 \\
\hline & $(0.787)$ & $(0.362)$ & $(0.835)$ \\
\hline Bureau & -0.047 & -0.004 & -0.054 \\
\hline & $(-0.904)$ & $(-0.069)$ & $(-0.951)$ \\
\hline Democ & $0.269 * * *$ & $0.252^{* * *}$ & $0.284 * * *$ \\
\hline & $(4.713)$ & $(4.471)$ & $(4.857)$ \\
\hline $\mathrm{R}^{2}$ & 0.207 & 0.219 & 0.205 \\
\hline Adj-R $^{2}$ & 0.192 & 0.204 & 0.190 \\
\hline $\mathrm{F}$ & $13.631^{* * *}$ & $14.607^{* * *}$ & $13.463^{* * *}$ \\
\hline & & & \\
\hline & $(1)$ & $(2)$ & (3) \\
\hline IDV & $0.049 *$ & & \\
\hline & $(1.852)$ & & \\
\hline STO & & $0.120^{* *}$ & \\
\hline & & $(2.506)$ & \\
\hline UAI & & & $-0.120 * *$ \\
\hline & & & $(-2.235)$ \\
\hline GDPp & $-0.153^{* * *}$ & $-0.156^{* * *}$ & $-0.170^{* * *}$ \\
\hline & $(-3.306)$ & $(-3.410)$ & $(-3.692)$ \\
\hline Growth & -0.044 & -0.031 & -0.046 \\
\hline & $(-0.897)$ & $(-0.635)$ & $(-0.956)$ \\
\hline Infl & $0.197 * * *$ & $0.193^{* * *}$ & $0.192 * * *$ \\
\hline & $(4.225)$ & $(4.147)$ & $(4.126)$ \\
\hline Unem & -0.037 & -0.019 & 0.001 \\
\hline & $(-0.721)$ & $(-0.372)$ & $(0.012)$ \\
\hline Law & 0.016 & 0.003 & 0.055 \\
\hline & $(0.288)$ & $(0.061)$ & $(1.037)$ \\
\hline Stab & 0.052 & 0.031 & 0.055 \\
\hline & $(0.918)$ & $(0.542)$ & $(0.982)$ \\
\hline Bureau & -0.051 & -0.010 & -0.109 \\
\hline & $(-0.905)$ & $(-0.167)$ & $(-1.800)$ \\
\hline Democ & $0.133^{* *}$ & $0.116^{*}$ & $0.186^{* * *}$ \\
\hline & $(2.156)$ & $(1.913)$ & $(2.971)$ \\
\hline $\mathrm{R}^{2}$ & 0.079 & 0.089 & 0.087 \\
\hline Adj-R $^{2}$ & 0.061 & 0.072 & 0.070 \\
\hline $\mathrm{F}$ & $4.485^{* * *}$ & $5.133 * * *$ & $4.978 * * *$ \\
\hline
\end{tabular}




\section{Conclusion}

BRI is the top-level design of China's economic diplomacy and a major practice in building a community with a shared future for mankind. It aims to promote win-win cooperation for common development and common prosperity and provides infrastructure financing for BRI countries. However, the debt issues of BRI countries make BRI project to be questioned in the international community. Failing to clarify the debt issues of BRI countries may have a negative impact on China's efforts to rebuild its relationship with developing countries. Therefore, in-depth analysis of the factors affecting the debt risk of BRI countries is crucial to the smooth implementation and high-quality development of the BRI project.

Based on data from 65 BRI countries during the period from 2008 to 2017, the paper selects three cultural dimensions,includingindividualism, short-term orientation and uncertainty avoidance, to explore the impact of national culture on debt risk and analyze from the perspective of social values, preferences and risk perception in different cultural backgrounds. The empirical results show that strong individualism and short-term orientation leads to higher national debt risk, whilestronger uncertainty avoidance leads to lower national debt risk.Due to international cooperation may affect national debt risk from solvency and willingness to repay, this paper further considers the moderating effect of international cooperation on culture and debt risk. It shows that international cooperation alleviates the negative influence of culture on debt risk.

This paper proposes to add cultural dimension to the assessment of the debt risk of BRI countries, and it provides empirical analysis and supplement to the existing research from the perspective of informal institution. What needs to be emphasized is that our study on the impact of culture on national debt risk does not aim to seek the best culture in the world or to rank different cultures, nor to advocate any cultural revolution, but to better understand different cultures. Our research aims to better understand tradeoffs implied by different cultures which are deeply rooted in history. In this way, it can facilitate the communication and smooth financing across cultures.

\section{References}

[1] Arellano, C. (2008) Default Risk and Income Fluctuations in Emerging Economies. American Economic Review, 98, 690-712.

[2] Draksaite, A. (2011) Assessment of the Sustainability of Government Debt in a Stochastic Economy. Intellectual Economics, 5, 401-415.

[3] Eaton, J., Gersovitz, M. (1981) Debt with Potential Repudiation: Theoretical and Empirical Analysis. Review of Economic Studies, 48, 289-309.

[4] Wright, M. L. J. (2012) The Theory of Sovereign Debt and Default. In Encyclopedia of Financial Globalization. Ed. Gerard Caprio.

[5] PricewaterhouseCoopers. 2008. Reward: A new paradigm? http://www.pwc.com/gx/en/banking-capital-markets/pdf/Reward.pdf.

[6] Alesina, A., Giuliano, P. (2015) Culture and Institutions. Journal of Economic Literature, 53(4), 898-944.

[7] Guiso, L., Sapienza, P., Zingales, L. (2006) Does Culture Affect Economic Outcomes?. The Journal of Economic Perspectives, 20(2), 23-48.

[8] Guiso, L., Sapienza, P., Zingales, L. (2009) Cultural Biases in Economic Exchange?.The Quarterly Journal of Economics, 124(3), 1095-1131.

[9] Gleason, K. C., Mathur, L. K., Mathur, I. (2000) The Interrelationship Between Culture, Capital Structure and Performance: Evidence from European Retailers. Journal of Business Research, 50, 185-191.

[10] Sekely, W. S.,Collins, J. M. (1988) Cultural Influences on International Capital Structure. 
Journal of International Business Studies, 19(1), 87-100.

[11] Chui, A. C. W., Kwok, C. C. Y., Zhou, G. (2016) National Culture and the Cost of Debt. Journal of Banking \& Finance, 69, 1-15.

[12] Wang, D., Esqueda, O. A. (2014) National Cultural Effects on Leverage Decisions: Evidence from Emerging-market ADRs. Research in International Business and Finance, 31, 152-177.

[13] Hofstede, G., Hofstede, G. J., Minkov, M. (2010) Cultures and Organizations: Software of the Mind. Revised and Expanded 3rd Edition, New York: McGraw-Hill USA.

[14] Hofstede, G., Bond, M. (1988) The Confucius Connection: From Cultural Roots to Economic Growth. Organizational Dynamics, 16(4), 4-21.

[15] Boubakri, N., Mirzaei, A., Samet, A. (2017) National Culture and Bank Performance: Evidence from the Recent Financial Crisis. Journal of Financial Stability, 29, 36-56.

[16] Fidrmuc, J. P., Jacob, M. (2010) Culture, Agency Costs, and Dividends. Journal of Comparative Economics, 38, 321-339.

[17] Gorodnichenko, Y., Roland, G. (2011) Which Dimensions of Culture Matter for Long-Run Growth?. American Economic Review, 101(3), 492-498.

[18] Kristjansdottir, H., Gudlaugsson,T. O., Gudmundsdottir S., Gylfi D. A.(2017) Hofstede National Culture and International Trade. Applied Economics, 49(55), 5792-5801.

[19] Lim, C. Y., Kiridaran, K., Gerald, J. (2011) Effects of National Culture on Earnings Quality of Banks. Journal of International Business Studies, 42(6), 853-874.

[20] Mourouzidou-Damtsa, S., Milidonis, A., Stathopoulos, K. (2017) National Culture and Bank Risk-Taking. Journal of Financial Stability, http://dx.doi.org/10.1016/j.jfs.2017.08.007.

[21] Hofstede, G. (2001) Culture’s Consequences: Comparing Values, Behaviors, Institutions, and Organizations across Nations. New York, NY: Sage.

[22] Licht, A., Goldschmidt, C., Schwartz, S. H. (2005) Culture, Law, and Corporate Governance. International Review of Law and Economics, 25(2), 229-255.

[23] Shane, S. A., Venkataraman, S. (1996) Renegade and Rational Championing Strategies. Organization Studies, 17(5), 751- 777.

[24] Hofstede, G., Minkov, M. (2010) Long-versus Short-term Orientation: New Perspectives. Asia Pacific Business Review, 16(4), 493-504.

[25] Chen, K. M. (2013) The Effect of Language on Economic Behavior: Evidence from Savings Rates, Health Behaviors, and Retirement Assets. American Economic Review, 103(2), 690-731.

[26] Chen, S., Cronqvist, H., Ni, S. (2017) Languages and Corporate Savings Behavior. Journal of Corporate Finance, 46, 320-341.

[27] Acharya, V. V., Rajan, R. G. (2013) Sovereign Debt, Government Myopia, and the Financial Sector. Review of Financial Studies, 26 (6), 1526-1560.

[28] Frijns, B., Gilbert, A., Lehnert, T. (2013) Uncertainty Avoidance, Risk Tolerance and Corporate Takeover Decisions. Journal of Banking \& Finance, 37(7), 2457-2471.

[29] Bontempo, R. N., Bottom, W. P., Weber, E. U. (1996) Cross-Cultural Differences in Risk Perception: A Model-Based Approach. Risk Analysis, 17(4).

[30] Kwok, C. C. Y., Tadesse, S. (2006) National Culture and Financial Systems. Journal of International Business Studies, 37(2), 227-247.

[31] Kohlscheen, E., O'Connell, S. A. A.(2007) Sovereign Debt Model with Trade Credit and Reserves. Unpublished Paper, University of Warwick. 
[32] IMF, Assessing Sustainability, IMF Staff Paper, No.02/28/2002.

[33] Kraay, A. (2006) When Is External Debt Sustainable?. World Bank Economic Review, 20(3), 341-365.

[34] Busse M, Nunnenkamp J K. FDI Promotion through Bilateral Investment Treaties: More than a Bit?. Review of World Economics, 2010, 146(1): 147-177

[35] Desbordes R, Vicard V. Foreign Direct Investment and Bilateral Investment Treaties: An International Political Perspective. Journal of Comparative Economics, 2009, 37(3): 300-386

[36] Neumayer, E., Spess, L. (2005) Do Bilateral Investment Treaties Increase Foreign Direct Investment to Developing Countries?. International Finance, 33(10): 1567-1585.

[37] Elgin, C., Uras, B. R. (2013) Public Debt, Sovereign Default Risk and Shadow Economy. Journal of Financial Stability, 9(4), 628-640.

[38] Hofstede, G. (1980) Culture's Consequences: International Differences in Work Related Values. Beverly Hills, CA: Sage Publications. 